\title{
Sedimentology and geochemistry of carbonates from lacustrine sequences in the Madrid Basin, central Spain
}

\author{
J.P. Calvo a,*, B.F. Jones b, M. Bustillo a, R. Fort c, A.M. Alonso Zarza c, C. Kendall b \\ " Departamento de Petrologia y Geoquimica, Universidad Complutense, E-28040 Madrid . Spain \\ " U.S. GeolOf!ical Survev. Reston. VA22092. USA
}

\begin{abstract}
Lacustrine and alluvial carbonate facies have been investigated in Middle Miocene successions of the western side of the Madrid Basin in order to evaluate paleoenvironments in which carbonates formed. Carbonate facies are varied and include: ( I) calcrete and dolocrete; (2) pond deposits; ( 3) lake margin dolostone; (4) mudflat carbonate; and (5) open-lake carbonate facies. The dominant mineralogy of these is dolomite and/ or low-Mg calcite. No high-Mg calcite or aragonite have been detected in any sample. $8^{18} 0$ - and $8^{13} \mathrm{C}$-values range from -8.20 to $-1.80 \% 0$ PDB and -10.25 to $-0.70 \% 0$ PBD, respectively. More negative $8^{18} 0$ - and $8^{13} \mathrm{C}$-values correspond to predominantly calcite calcretes and to carbonate deposited in ponds at the foot of arkosic alluvium. Higher $8^{18} 0$-values are from both lacustrine carbonate and dolocrete. This latter lithofacies has strong geochemical similarities to dolostones deposited in a lake margin environment. Mudflat carbonate, deposited on shallow platforms subject to lake water oscillation, shows great heterogeneity in both stable isotope value and trace-element content. The mineralogy of these carbonates is dominated by calcite and the limestones contain molds of gypsum. Occurrence of calcitized dolomite textures in these facies suggests the influence of fresher water during expanding lacustrine cycles or further interaction with less saline groundwater. Trace-element contents are considered to be potential indicators of the different carbonate facies types, thus aiding the paleoenvironmental interpretation. However, discrimination among carbonate facies on the basis of trace-element contents appears to be dependent on the statistical method utilized for treatment of data. More information is needed to ascertain their use as paleoenvironmental indicators.
\end{abstract}

\section{Introduction}

Sedimentological research on carbonate deposits from ancient lacustrine sequences deposited under a variety of geological and paleoclimatic conditions have contributed to establishing sedimentological models (Eugster and Kelts, 1983; Allen and Collinson, 1986; Tucker and Wright, 1990; Platt and Wright, 1991) which constitute the current basis for the interpretation of lacustrine deposits. The chemical composition of carbonate deposits in lacustrine sequences has been used to characterize the hydrogeochemistry of the paleolake basin and, in a few cases, has also been used to deduce paleoclimatic changes (Molenaar and DeFeyter, 1985; Gasse et al., 1987; Janaway and Parnell, 1989; Bellanca et al., 1992). Isotope geochemistry in particular is increasingly used to obtain paleoenvironmental information, including paleohydrology, paleoclimate and the role of photosynthetic activity in the orecioitation oflake carbonate (Fritz and Fontes. 1986; 
Talbot, 1990; Talbot and Kelts, 1990; Kelts and Talbot, 1990).

This paper deals with Miocene lacustrine carbonates deposited on the western side of the Madrid Basin in central Spain. Previous work (Calvo et al., 1984, 1989; Hoyos et al., 1985; Lomoschitz et al., 1985; Alonso et al., 1986) demonstrates that these formed in several environments related to a shallow, brackish lake whose open areas extended across the central and eastern parts of the basin (Calvo et al., 1989). Some isotopic values of the carbonates were evaluated by Ord6fiez et al. (1983) and Calvo et al. (1991) in a general overview of sulphates and carbonates of the Madrid Basin. A geochemical study of these carbonates has been carried out in order to define variations in trace-element content and stable isotope composition of non-elastic carbonates deposited in different lake subenvironments and to evaluate the discrimination capability of such geochemical data when applied to a comparison of sedimentary settings.

\section{Geological setting}

The Madrid Basin is a complex intracratonic basin located in the centre of the Iberian Peninsula (Fig. 1). The basin was filled by up to $3500 \mathrm{~m}$ of continental strata during the Tertiary. Tectonic movements related to the Alpine Orogeny resulted in folding and faulting of previously deposited Paleogene sequences ( Calvo et al., 1989). This is clearly seen along the basin margins where the Miocene deposits lie unconformably over the Paleogene. From the Early Miocene until the beginning of the Late Miocene, the area has been a hydrologic and geomorphologic closed basin in which a succession of lake complexes developed. The first of these complexes corresponds to the Lower Miocene (Agenian-Early Aragonian) and was dominated by the sedimentation of Na-Ca-sulphate and lesser chloride evaporite deposits (Ord6fiez et al., 1991).

These evaporites are overlain disconformably by a 50-80-m-thick sequence of lacustrine carbonate and gypsum in central areas of the basin, stratigraphically integrated in the so-called Intermediate Unit of the Miocene in the Madrid Basin ( Alberdi et al., 1983). The major sedimentological features of this unit, ranging in age from Middle Aragonian to Lower Vallesian, have been described by Calvo et al. (1989). A simplified

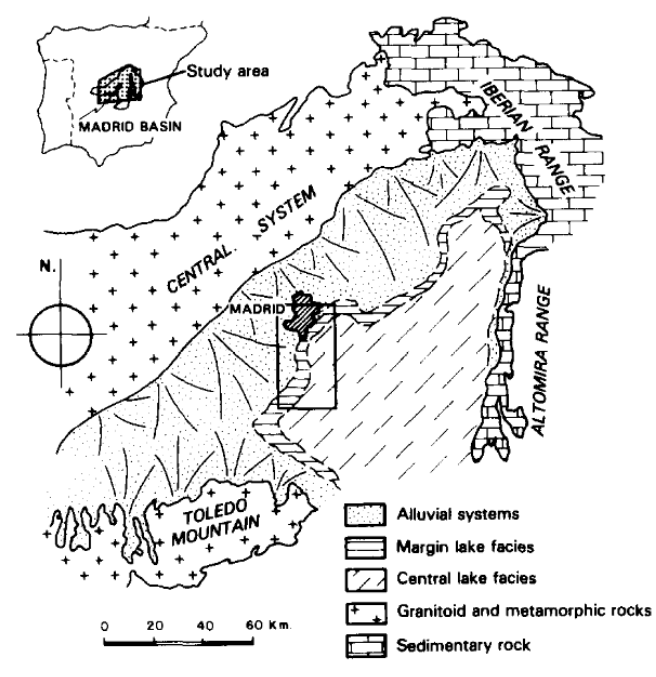

Fig. 1. Simplified sketch of depositional systems in the Madrid Basin during the middle Aragonian with location of the study area. The rectangle in the central part of the map limits the working area sketched in Fig. 2.

scheme of the distribution of major facies in the basin during this period is shown in Fig. 1. Sedimentation changed toward the Lower Vallesian, reflecting expansion and freshening of the lake system. Freshwater carbonate deposits dominate the uppermost part of the unit. In many areas, these capping carbonates show paleokarstic features which suggest that the Intermediate Unit was exposed for a long period (Cafiaveras et al., 1995) prior to the deposition of terrigenouscarbonate strata which constitute the third and the last of the major Miocene lacustrine sequences in the basin.

\section{Materials and methods}

For this study we have selected a number of lithologic sections that crop out in the western part of the Madrid Basin. All are stratigraphically related to the Intermediate Unit ( Fig. 2) . Sections were selected according to the distribution of the lacustrine sedimentary facies at the distal parts of the alluviums that fringe in a concentric pattern the basin ( Fig. 1). In this way, our study is centered on the carbonate facies that record the transition from lake margin to open-lake environ- 


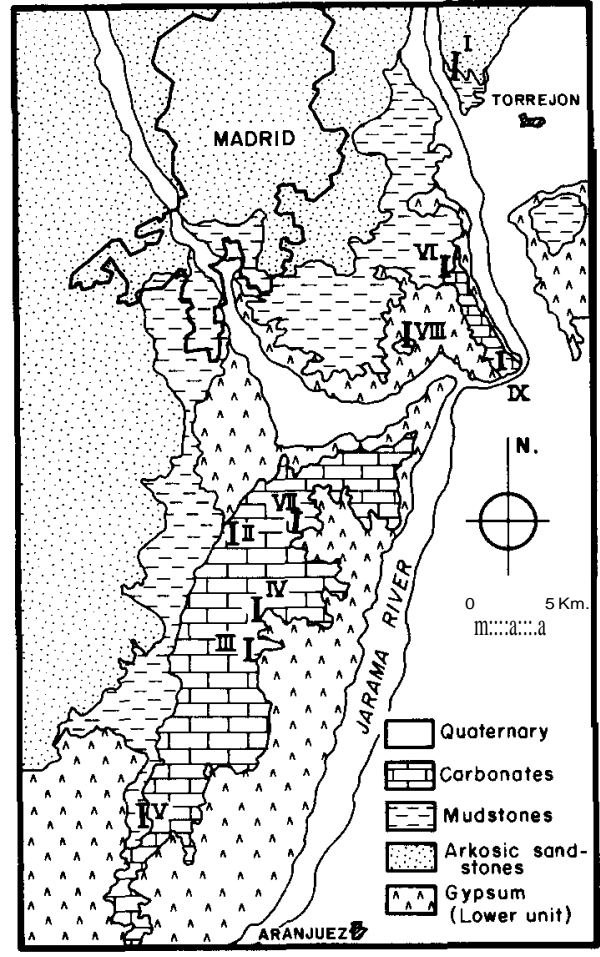

Fig. 2. Geologic map of the study area with bars showing the location of the lithostratigraphic logs (I-IX) presented in Fig. 3.

ments (see Fig. 4) (Calvo et al., 1989). Carbonate samples from these localities were supplemented by samples from isolated outcrops in the area.

Fig. 3 shows the correlation of the selected lithostratigraphic logs. Section I ( Paracuellos de Jarama area) contains distal facies of arkosic alluvium from the northwestern margin of the basin, and consists of an alternation of fine arkosic deposits, sandy mudstones, dolocretes and calcretes that prograded over marginal lake deposits ( lowermost part of the section ). Sections $11-\mathrm{V}$ correspond to marginal and mudflat carbonate facies that were variably influenced by influx of medium- to coarse-grained terrigenous deposits. Sections VI, VIII and IX are formed in the basal part of the mudflat facies, characterized by the alternation of carbonate and laminated mudstone. These deposits are overlain by more continuous and thicker carbonate beds representative of open-lake facies. Mudstones decrease both in frequency and thickness from the lake margin to the open lake.

Cyclicity recognized in most of the sections suggests repeated fluctuations in lake level. In addition, a pro- gressive lake expansion is indicated towards the top of the Intermediate Unit. This episode is marked by the development of carbonate deposits in sections VII-IX, and has been studied in some detail by Bellanca et al. ( 1992). The uppermost deposits in these sections display features related to a widespread episode of karstification during the Vallesian ( Calvo et al., 1984; Ord6fiez et al., 1985; Cafiaveras et al., 1995).

Ninety-one samples of carbonate ( both limestone and dolostone) were collected for mineralogical and chemical analysis (Tables 1 and 2). The samples were chosen to represent specific carbonate layers, covering most representative carbonate facies in the area. Sampling points from lithologic sections are depicted in Fig. 3 whereas the remaining samples were collected from discontinuous outcrops. From this set of samples, only 32 were selected for isotopic analyses (Table 2) as they were considered to be quite representative of the different carbonate facies. Samples 82-90 were collected in a second phase of the work in order to investigate a specific carbonate type ( calcrete) in more detail. Gypsum was not detected in significant amounts in any of the samples. Only very small traces of gypsum occur in carbonates containing lenticular molds. The samples were analyzed for mineralogical composition using a Philips ${ }^{\circledR}$ X-ray diffraction ( XRD) system operated at $40 \mathrm{kV}$ and $30 \mathrm{~mA}$, and a monochromated $\mathrm{Cu}-$ $\mathrm{K}$,radiation. The Mg content in calcite was determined according to the method proposed by Goldsmith and Graf ( 1958). With pure quartz as an internal standard, the reflections used were (104) for calcite and (101) for quartz. $\mathrm{Mg}$ contents (mole\%) were $<5 \%$ in all samples.

Subsamples ( $1 \mathrm{~g}$ ) of the limestone and dolostone powders were treated with $50 \mathrm{ml}$ of $4 \%$ ( v/ v ) hydrochloric acid for 4 and $24 \mathrm{hr}$, respectively, at room temperature. Under these conditions, the alteration of the non-carbonate fraction ( clays, sand-sized minerals) is minimal. The insoluble residues were collected on filter paper to determine percentage insoluble residue by gravimetric methods.

All solutions were analyzed by atomic absorption spectrophotometry for determination of $\mathrm{Li}, \mathrm{Na}, \mathrm{K}, \mathrm{Fe}$, $\mathrm{Mn}$ and Sr. The analytical results are given as concentrations recalculated on a pure carbonate (insoluble residue-free) basis (Table 1).

For stable isotopic analysis, all samples were ground to pass through a 100-mesh sieve; the 250-mesh frac- 


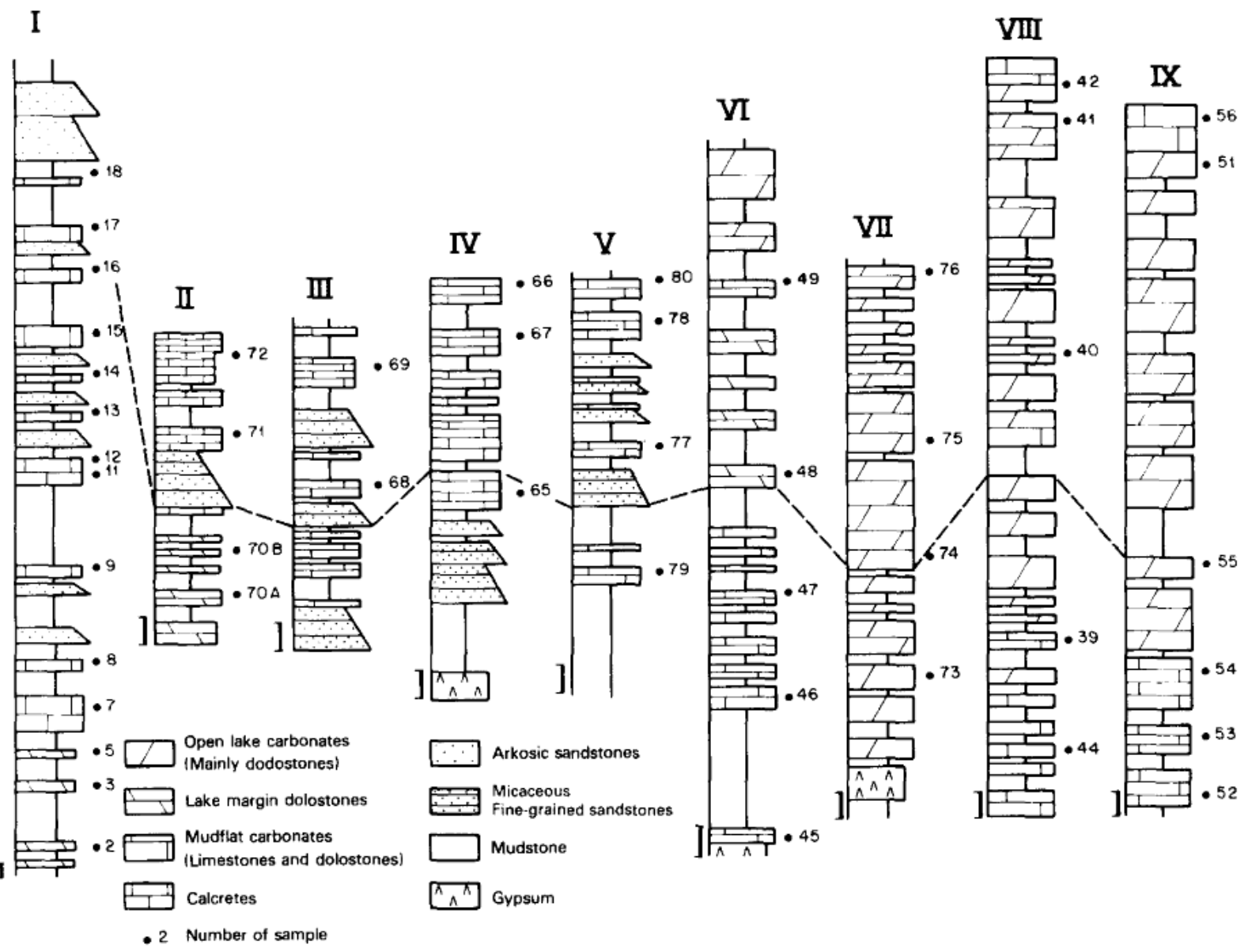

Fig. 3. Lithostratigraphic logs studied and location of the collected samples. Bars at the foot of the logs are equivalent to $1 \mathrm{~m}$ in all cases. Dashed line indicates stratigraphic correlation among sections.

tion was saved for analysis. For mixed carbonate samples, both calcite and dolomite were analyzed if the lesser mineral constituted at least $10 \%$ of the total carbonate; otherwise, only the dominant mineral was analyzed. Carbon dioxide was evolved from each sample at $25^{\circ} \mathrm{C}$ using $100 \% \mathrm{H}_{3} \mathrm{PO}_{4}$. The gas evolved in the first hour was analyzed as calcite; the gas evolved between $24 \mathrm{hr}$ and 7 days was analyzed as dolomite. All samples were prepared and analyzed at least in duplicate. The analytical precision is generally $\pm 0.10 \% 0$ for carbon and $\pm 0.15 \% 0$ for oxygen, except for a few samples that posed severe analytical problems. Oxygen and carbon values are reported in permil relative to PDB.

Both factor analysis, performed through varimax rotation process, and discriminant function analysis were used for treatment of data. Trace-element contents and insoluble residues from the carbonate samples were included for the analysis. Discriminant function analysis was first applied to the trace-element data. Canonical correlations and the eigenvalues were obtained for each discriminant function ( Klovan and Billings, 1967). Two discriminant functions were obtained and the samples plotted on an bi-axial diagram. The application of the discriminant function analysis to a combined set of trace-element and stable isotope contents did not lead to significant results probably because of the relatively reduced number of isotopic data.

\section{Petrology of carbonate deposits}

Carbonate deposits in the study area show different facies which are related to several depositional envi- 
ronments (Calvo et al., 1984, 1989; Lomoschitz et al., 1985; Alonso et al., 1986; Alonso Zarza et al., 1992). Such environments represent the transition from distal alluvial fan zones and adjoining lake margin settings to mudflat and open-lake areas. Five carbonate facies have been distinguished: (1) calcrete and dolocrete; (2) carbonate pond facies; (3) lake margin dolostone; (4) mudflat carbonate; and (5) open-lake carbonate facies.

\subsection{Calcretes and dolocretes}

Calcrete profiles consist of nodular, prismatic and platy facies (Esteban and Klappa, 1983) and locally show small root traces. Single calcrete profiles range from 0.4 to $1.8 \mathrm{~m}$ in thickness and occur as beds separated by arkosic sandstone and Ior sandy mudstone, or are locally amalgamated ( "composite paleosols" of Wright, 1989) . Some differences concerning paleogeographic location of the calcretes can be outlined. Thus, a set of calcretes is located in the medial zone of arkosic alluvium (samples 82-90, see Table 2) ; herein, the calcrete is characterized by both broad development of alveolar-septa) structures (Klappa, 1980) that disrupt former clay cutans and massive replacement of pedologic clay textures by low-Mg micrite. All these features suggest that calcrete developed on a previous soil.

Other calcretes (samples 7-18) formed on distal alluvial zones. In this setting, carbonate in the lower part of the calcrete profiles consists of cracked micrite and abundant clay aggregates. These clays are mostly dioctahedral smectites, although sepiolite has also been recognized. Carbonate content increases toward the upper parts of profiles where textures consist of dense to clotted micrite displaying alveolar features, desiccation cracks, and lumpy to pelloidal fabrics (Calvet and Julia, 1983). This calcrete type is mostly composed of low-Mg calcite.

Finally, a third type of paleosol comprises dolocretes (in the sense of Netterberg, 1980) that developed close to the lake margin facies (described below). This carbonate (several samples listed in Table 1) contains typical calcrete textures such as irregular spar-filled cracks, floating detrital grains, dense crystalline matrices and etched silicate grains ( Alonso Zarza et al., 1992). Dolomite occurs as contorted dolomicrite veins, coated by fine to medium crystalline dolomite cement, separating areas of locally strongly orientated clays. The presence of analcime, averaging $5-10 \%$ of the total rock, has been often determined from the dolocrete profiles.

\subsection{Carbonate pond facies}

Carbonate pond facies occur locally at the foot of arkosic alluvium between distal fan and lake margin facies (Fig. 4) . Good examples of this facies have been observed in locations close to section I of Fig. 3. Ponds fed by relatively fresh, silica-bearing surface or groundwater were sites for the accumulation of bedded nodular carbonate and cream to whitish sepiolitic clay (Calvo et al., 1986; Doval et al., 1986). The total thickness of the deposits averages $4 \mathrm{~m}$. Carbonates are predominantly calcite as homogeneous dense micrite with alveolar root textures, fenestral voids, isolated clay aggregates, and scarce fragments of gastropods and ostracods. Contact between clay and carbonate in alternating beds is usually transitional.

\subsection{Lake margin dolostones}

Lake margin dolomite occurs interbedded with green clay in monotonous 2-4-m vertical successions wherein Mg-rich smectites grade upward into pink clay to dolostone. Doval et al. ( 1986) and Martfn de Vidales et al. ( 1989) indicate that pink clay is kerolite-stevensite mixed-layer material.

Tabular dolostone beds exhibit characteristic nodular or concretionary structures and consist of micrite to microsparite with abundant desiccation cracks. Dolomites lack fossils but occasionally contain bioturbation traces of worms or roots. Dolomites also contain dispersed micrite lumps or clay aggregates.

\subsection{Mudflat carbonates}

Mudflat carbonate occurs between lake margin dolostone and open-lake carbonate that extends toward central parts of the basin (Fig. 4). Mudflat carbonate can be traced laterally some $2-3 \mathrm{~km}$ in width, while the abundance of interbedded mudstone decreases toward open lacustrine areas. These beds form characteristically the upper part of upward shoaling cycles that represent the transition from high to low stands of the lake. 
Table I

Trace-element composition and mineralogy of carbonates

\begin{tabular}{|c|c|c|c|c|c|c|c|c|c|c|c|c|c|c|c|}
\hline Sample & $\mathrm{Na}$ & $\mathrm{K}$ & $\mathrm{Li}$ & $\mathrm{Fe}$ & $\mathrm{Mn}$ & $\mathrm{Sr}$ & I.R. & Calcite & Dolomite & $\begin{array}{l}\text { Carbonate } \\
\text { facies }\end{array}$ & $\begin{array}{l}\text { Number } \\
\text { of facies }\end{array}$ & l'Na,Li,Fe,Mn,Sr & $\mathrm{Sr}$ & $\mathrm{Na}$ & l:Li,Fe,Mn \\
\hline 2 & 728 & 894 & 27 & 943 & 640 & 63 & 32.6 & 0 & 100 & $\begin{array}{l}\text { lake margin } \\
\text { dolostones }\end{array}$ & & 2.401 & 2.62 & 30.32 & 67.06 \\
\hline 5 & 3.947 & 422 & 33 & 775 & 697 & 58 & 16.4 & 10 & 90 & dolocretes & 6 & 5,510 & I.OS & 71.63 & 27.31 \\
\hline 6 & 125 & 91 & 3 & 211 & 80 & 232 & 20.9 & 0 & 100 & calcretes & 2 & 651 & 35.64 & 19.20 & 45.16 \\
\hline 7 & 73 & 83 & & 178 & 84 & 163 & 0.4 & 100 & 0 & calcretes & 2 & 501 & 32.53 & 14.57 & 52.89 \\
\hline li & 246 & 206 & 4 & 220 & 88 & 442 & 17.5 & 100 & 0 & calcretes & 2 & 1,000 & 44.20 & 24.60 & 31.20 \\
\hline 9 & 159 & 458 & 13 & 459 & 80 & 80 & 33 & 100 & 0 & calcretes & 2 & 791 & 10.11 & 20.10 & 69.79 \\
\hline jo & 98 & 260 & 6 & 311 & 48 & 139 & 20.9 & 100 & 0 & calcretes & 2 & 602 & 23.09 & 16.28 & 60.63 \\
\hline II & 73 & 283 & 3 & 178 & 84 & 163 & 0.4 & 100 & 0 & calcretes & 2 & 501 & 32.53 & 14.57 & 52.89 \\
\hline 12 & 98 & 260 & 6 & 311 & 48 & 139 & 20.9 & 100 & 0 & calcretes & 2 & 602 & 23.09 & 16.28 & 60.63 \\
\hline 13 & 366 & 225 & 13 & 189 & 182 & 169 & 18.1 & 100 & 0 & calcretes & 2 & 919 & 18.39 & 39.83 & 41.78 \\
\hline 15 & 81 & 70 & 2 & 86 & 35 & 165 & 4.5 & 100 & 0 & calcretes & 2 & 369 & 44.72 & 21.95 & 33.33 \\
\hline 16 & 103 & 202 & & 175 & 76 & 116 & 16.7 & 100 & 0 & calcretes & 2 & 475 & 24.42 & 21.68 & 53.89 \\
\hline 17 & 204 & 353 & 20 & 318 & 49 & 219 & 25.3 & 100 & 0 & calcretes & 2 & 810 & 27.04 & 25.19 & 47.78 \\
\hline Iii & 355 & 274 & 27 & 510 & 138 & 37 & 22.4 & 100 & 0 & calcretes & 2 & 1,067 & 3.47 & 33.27 & 63.26 \\
\hline 23 & 311 & 318 & 18 & III & 34 & 295 & 37.7 & 100 & 0 & cakretes & 2 & 769 & 38.36 & 40.44 & 21.20 \\
\hline 25 & 331 & 669 & 40 & 132 & 457 & 107 & 21.1 & 0 & 100 & $\begin{array}{l}\text { lake margin } \\
\text { dolostones }\end{array}$ & & 1,067 & 10.03 & 31.02 & 58.95 \\
\hline 26 & 258 & 434 & 22 & 590 & 264 & IOI & 11.7 & 0 & 100 & $\begin{array}{l}\text { lake margin } \\
\text { dolostones }\end{array}$ & & 1.235 & 8.18 & 20.89 & 70.93 \\
\hline 27 & 265 & 162 & 19 & 285 & 1,808 & 38 & 14.1 & 0 & 100 & dolocretes & 6 & 2.415 & 1.57 & 10.97 & 87.45 \\
\hline 29 & 4,555 & 618 & 35 & 1,083 & 540 & 118 & 22.3 & 0 & 100 & dolocretes & 6 & 6,331 & 1.86 & 71.95 & 26.19 \\
\hline 30 & 1,260 & 841 & 18 & 434 & 796 & 141 & 9.5 & 0 & 100 & dolocretes & 6 & 2,649 & 5.32 & 47.57 & 47.11 \\
\hline 32 & 697 & 230 & 2 & 183 & 64 & 137 & 21.5 & 100 & 0 & $\begin{array}{l}\text { carbonate } \\
\text { ponds }\end{array}$ & & 1,083 & 12.65 & 64.36 & 22.99 \\
\hline 33 & 372 & 72 & 2 & 87 & 28 & 181 & 5.7 & 100 & 0 & $\begin{array}{l}\text { carbonate } \\
\text { ponds }\end{array}$ & & 670 & 27.01 & 55.52 & 17.46 \\
\hline 34 & 130 & 86 & & 114 & 80 & 170 & 8.5 & 100 & 0 & $\begin{array}{l}\text { carbonate } \\
\text { ponds }\end{array}$ & 3 & 497 & 34.21 & 26.16 & 39.64 \\
\hline 35 & 111 & 525 & 14 & 1,101 & 116 & 3,002 & 17.2 & 100 & 0 & $\begin{array}{l}\text { mudflat } \\
\text { carbonates }\end{array}$ & 4 & 4,344 & 69.11 & 2.56 & 28.34 \\
\hline 36 & 405 & 117 & 35 & 295 & 218 & 152 & 4.8 & 0 & 100 & $\begin{array}{l}\text { lake margin } \\
\text { dolostones }\end{array}$ & & 1,105 & 13.76 & 36.65 & 49.59 \\
\hline 37 & 96 & 161 & 11 & 430 & 68 & 3,519 & 5.1 & 100 & 0 & $\begin{array}{l}\text { mudflat } \\
\text { carbonates }\end{array}$ & 4 & 4,124 & 85.33 & 2.33 & 12.34 \\
\hline 38 & 66 & 124 & 7 & 250 & 75 & 2,738 & 7.4 & 100 & 0 & $\begin{array}{l}\text { mudflat } \\
\text { carbonates }\end{array}$ & 4 & 3,136 & 87.31 & 2.10 & 10.59 \\
\hline 39 & 296 & 214 & 27 & 1.354 & 172 & 149 & 7.1 & 0 & 100 & $\begin{array}{l}\text { mudflat } \\
\text { carbonates }\end{array}$ & 4 & 1,998 & 7.46 & 14.81 & 77.73 \\
\hline $4 \odot$ & 768 & 64 & & 351 & 155 & 138 & 3.4 & 0 & 100 & $\begin{array}{l}\text { mudflat } \\
\text { carbonates }\end{array}$ & 4 & 1.420 & 9.72 & 54.08 & 36.20 \\
\hline 41 & 335 & 170 & 24 & 396 & 76 & 161 & 15.4 & 0 & 100 & $\begin{array}{l}\text { open-lake } \\
\text { carbonates }\end{array}$ & 5 & 992 & 16.23 & 33.77 & 50.00 \\
\hline 42 & 493 & 84 & 18 & 428 & 223 & 202 & 3.2 & 0 & 100 & $\begin{array}{l}\text { open-lake } \\
\text { carbonates }\end{array}$ & & 1,364 & 14.81 & 36.14 & 49.05 \\
\hline 44 & 155 & 268 & 13 & 854 & 190 & 394 & 14.6 & 100 & 0 & $\begin{array}{l}\text { mudflat } \\
\text { carbonates }\end{array}$ & 4 & 1,606 & 24.53 & 9.65 & 65.82 \\
\hline 45 & 88 & 188 & & 510 & 54 & 1,160 & 9.1 & 100 & 0 & $\begin{array}{l}\text { mudflat } \\
\text { carbonates }\end{array}$ & 4 & 1,820 & 63.74 & 4.84 & 31.43 \\
\hline 46 & 214 & 226 & 8 & 1,302 & 328 & 1,034 & I I.I & 30 & 70 & $\begin{array}{l}\text { mudflat } \\
\text { carbonates }\end{array}$ & 4 & 2,886 & 35.83 & 7.42 & 56.76 \\
\hline 47 & 236 & 384 & 25 & 1,886 & 785 & 629 & 19 & 0 & 100 & $\begin{array}{l}\text { mudflat } \\
\text { carbonates }\end{array}$ & 4 & 3,561 & 17.66 & 6.63 & 75.71 \\
\hline 411 & 231 & 104 & 48 & 573 & 504 & 958 & 6.6 & 0 & 100 & $\begin{array}{l}\text { lake margin } \\
\text { dolostones }\end{array}$ & & 2,314 & 41.40 & 9.98 & 48.62 \\
\hline 49 & 196 & 126 & 14 & 1,200 & 275 & 138 & 2.5 & 65 & 35 & $\begin{array}{l}\text { mudflat } \\
\text { carbonates }\end{array}$ & 4 & 1,823 & 7.57 & 10.75 & 81.68 \\
\hline 50 & 498 & 127 & 16 & 1,334 & 333 & 135 & & 0 & 100 & $\begin{array}{l}\text { mudflat } \\
\text { carbonates }\end{array}$ & 4 & 2,316 & 5.83 & 21.50 & 72.67 \\
\hline
\end{tabular}


Table I (continued)

\begin{tabular}{|c|c|c|c|c|c|c|c|c|c|c|c|c|c|c|c|}
\hline Sample & $\mathrm{Na}$ & K & $\mathrm{Li}$ & $\mathrm{Fe}$ & $\mathrm{Mn}$ & $\mathrm{Sr}$ & I.R. & Calcite & Dolomite & $\begin{array}{l}\text { Carbonate } \\
\text { facies }\end{array}$ & $\begin{array}{l}\text { Number } \\
\text { of facies }\end{array}$ & $\mathrm{lNa}, \mathrm{Li}, \mathrm{Fe}, \mathrm{Mn}, \mathrm{Sr}$ & $\mathrm{Sr}$ & $\mathrm{Na}$ & $. l l, \mathrm{i}, \mathrm{Fe}, \mathrm{Mn}$ \\
\hline 51 & 429 & 363 & 10 & 613 & 70 & 134 & 8.7 & 25 & 75 & $\begin{array}{l}\text { open-lake } \\
\text { carbonates }\end{array}$ & 5 & 1,256 & 10.67 & 34.16 & 55.18 \\
\hline 52 & 264 & 85 & 2 & 215 & 149 & 241 & 5.2 & 100 & 0 & $\begin{array}{l}\text { mudflat } \\
\text { carbonates }\end{array}$ & 4 & 871 & 27.67 & 30.31 & 42.02 \\
\hline 53 & 75 & 155 & 9 & 606 & 91 & 712 & 5.7 & 100 & 0 & $\begin{array}{l}\text { mudflat } \\
\text { carbonates }\end{array}$ & 4 & 1,493 & 47.69 & 5.02 & 47.29 \\
\hline 54 & 245 & 185 & 5 & 476 & 140 & 79 & 1.8 & 40 & 60 & $\begin{array}{l}\text { mudflat } \\
\text { carbonates }\end{array}$ & 4 & 945 & 8.36 & 25.93 & 65.71 \\
\hline 55 & 1,055 & 73 & 3 & 241 & 54 & 123 & 1.6 & 80 & 20 & $\begin{array}{l}\text { mudflat } \\
\text { carbonates }\end{array}$ & 4 & 1,476 & 8.33 & 71.48 & 20.19 \\
\hline 56 & 422 & 37 & & 179 & 109 & 165 & 0.8 & 75 & 25 & $\begin{array}{l}\text { open-lake } \\
\text { carbonates }\end{array}$ & 5 & 878 & 18.79 & 48.06 & 33.14 \\
\hline 58 & 904 & 105 & 11 & 428 & 120 & 203 & 8.8 & 0 & 100 & dolocretes & 6 & 1,666 & 12.18 & 54.26 & 33.55 \\
\hline $6 \odot$ & 106 & 106 & 13 & 435 & 898 & 45 & 6 & 0 & 100 & dolocretes & 6 & 1,497 & 3.01 & 7.08 & 89.91 \\
\hline 62 & 77 & 141 & 5 & 256 & 25 & 93 & 6 & 100 & 0 & calcretes & 2 & 456 & 20.39 & 16.89 & 62.72 \\
\hline 63 & 252 & 176 & 45 & 1,429 & 1,799 & 72 & 21 & 0 & 100 & $\begin{array}{l}\text { lake margin } \\
\text { dolostones }\end{array}$ & & 3,597 & 2.00 & 7.01 & 90.99 \\
\hline 64 & 164 & 139 & 36 & 1,678 & 1,349 & 52 & 9.9 & 100 & 0 & $\begin{array}{l}\text { lake margin } \\
\text { dolostones }\end{array}$ & & 3,279 & 1.59 & 5.00 & 93.41 \\
\hline 65 & 64 & 139 & 2 & 584 & 416 & 456 & 4.8 & 100 & 0 & $\begin{array}{l}\text { mudflat } \\
\text { carbonates }\end{array}$ & 4 & 1,522 & 29.96 & 4.20 & 65.83 \\
\hline 66 & 78 & 97 & 9 & 371 & 88 & 420 & 6.3 & 100 & 0 & $\begin{array}{l}\text { mudflat } \\
\text { carbonates }\end{array}$ & 4 & 966 & 43.48 & 8.07 & 48.45 \\
\hline 67 & 69 & 89 & 10 & 353 & 316 & 304 & 5.8 & 100 & 0 & $\begin{array}{l}\text { mudflat } \\
\text { carbonates }\end{array}$ & 4 & 1,052 & 28.90 & 6.56 & 64.54 \\
\hline 68 & 100 & 331 & & 580 & 425 & 233 & 10.3 & 100 & 0 & $\begin{array}{l}\text { mudflat } \\
\text { carbonates }\end{array}$ & 4 & 1,341 & 17.38 & 7.46 & 75.17 \\
\hline 69 & 142 & 135 & 10 & 539 & 143 & 336 & 6.6 & 80 & 20 & $\begin{array}{l}\text { mudflat } \\
\text { carbonates }\end{array}$ & 4 & 1,170 & 28.72 & 12.14 & 59.15 \\
\hline $70 a$ & 320 & 354 & 27 & 1,488 & 1,424 & 69 & 21.9 & 0 & 100 & $\begin{array}{l}\text { lake margin } \\
\text { dolostones }\end{array}$ & & 3,328 & 2.07 & 9.62 & 88.31 \\
\hline $70 \mathrm{~b}$ & 363 & 110 & 35 & 615 & 1,190 & 139 & 10.8 & 0 & 100 & $\begin{array}{l}\text { lake margin } \\
\text { dolostones }\end{array}$ & & 2,342 & 5.94 & 15.50 & 78.57 \\
\hline 71 & 387 & 147 & 25 & 663 & 470 & 74 & 14.3 & 0 & 100 & $\begin{array}{l}\text { lake margin } \\
\text { dolostones }\end{array}$ & & 1,619 & 4.57 & 23.90 & 71.53 \\
\hline 72 & 139 & 253 & 7 & 704 & 354 & 245 & 9.3 & 100 & 0 & $\begin{array}{l}\text { mudflat } \\
\text { carbonates }\end{array}$ & 4 & 1,449 & 16.91 & 9.59 & 73.50 \\
\hline 73 & 633 & 83 & 10 & 435 & 125 & 110 & 39.3 & 0 & 100 & $\begin{array}{l}\text { open-lake } \\
\text { carbonates }\end{array}$ & 5 & 1,313 & 8.38 & 48.21 & 43.41 \\
\hline 74 & 544 & 63 & 6 & 211 & 246 & 151 & 1.7 & 0 & 100 & $\begin{array}{l}\text { open-lake } \\
\text { carbonates }\end{array}$ & 5 & 1,158 & 13.04 & 46.98 & 39.98 \\
\hline 75 & 74 & 48 & 2 & 173 & 118 & 117 & 2.6 & 90 & 10 & $\begin{array}{l}\text { open-lake } \\
\text { carbonates }\end{array}$ & 5 & 484 & 24.17 & 15.29 & 60.54 \\
\hline 76 & 926 & 98 & 11 & 331 & 123 & 223 & 6.9 & 0 & 100 & $\begin{array}{l}\text { open-lake } \\
\text { carbonates }\end{array}$ & 5 & 1,614 & 13.82 & 57.37 & 28.81 \\
\hline 77 & 155 & 123 & 5 & 735 & 958 & 283 & 7.2 & 100 & 0 & $\begin{array}{l}\text { mudflat } \\
\text { carbonates }\end{array}$ & 4 & 2,136 & 13.25 & 7.26 & 79.49 \\
\hline 78 & 139 & 322 & 4 & 674 & 797 & 220 & 15.5 & 90 & 10 & $\begin{array}{l}\text { mudflat } \\
\text { carbonates }\end{array}$ & 4 & 1,834 & 12.00 & 7.58 & 80.43 \\
\hline 79 & 189 & 245 & & 459 & 601 & 260 & 7.2 & 100 & 0 & $\begin{array}{l}\text { mudflat } \\
\text { carbonates }\end{array}$ & 4 & 1,512 & 17.20 & 12.50 & 70.30 \\
\hline 80 & 129 & 182 & 4 & 765 & 339 & 377 & 5.2 & 100 & 0 & $\begin{array}{l}\text { mudflat } \\
\text { carbonates }\end{array}$ & 4 & 1,614 & 23.36 & 7.99 & 68.65 \\
\hline 81 & 905 & 187 & 14 & 409 & 302 & 164 & 11.5 & 0 & 100 & $\begin{array}{l}\text { mudflat } \\
\text { carbonates }\end{array}$ & 4 & 1,794 & 9.14 & 50.45 & 40.41 \\
\hline
\end{tabular}

Trace elements contents of the carbonate (insoluble residue-free) fraction expressed in ppm. I.R. insoluble residues (\%). Mineralogy in \%. 
Oxygen and carbon isotopic composition of carbonate

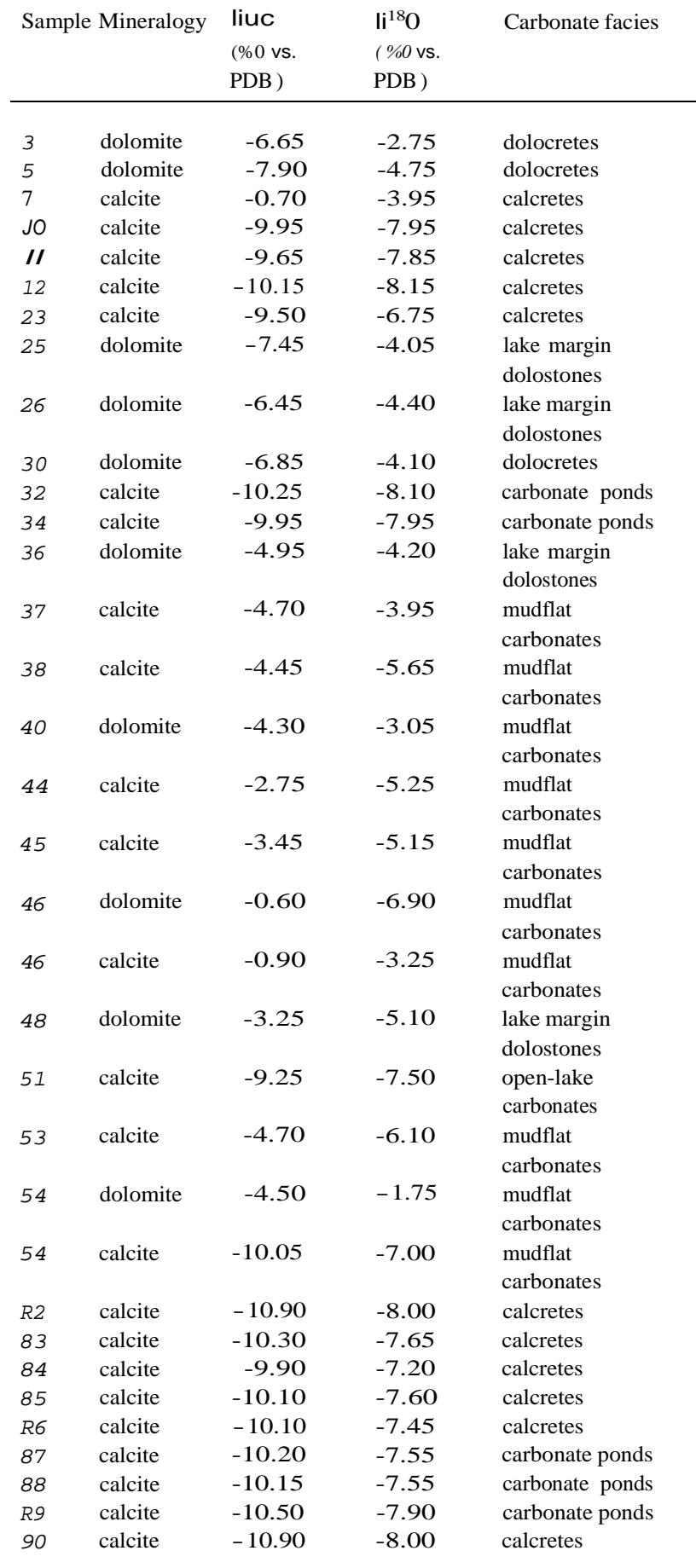

group. The most abundant facies is thinly bedded (2$4 \mathrm{~cm}$ thick), evenly laminated dolostone or limestone exhibiting a tabular geometry. These carbonates contain abundant molds oflenticular gypsum. Locally this type of carbonate exhibits gently domed, stromatolitelike shapes that are disrupted by desiccation cracks or tepee structures. The texture of the carbonate is varied, but is mostly composed of unimodal microsparite mosaics in which single crystals exhibit planar boundaries ( Sibley and Gregg, 1987). Many of the crystals have rhombohedral shapes characteristic of dolomite. These crystals are commonly red-stained and the bulk composition of the rock is calcite, as determined by XRD, which suggests that calcitization was a generalized process affecting precursor dolomite deposits. Transformation of dolomite to calcite could be related to periodic shoaling accompanied by influx of meteoric water over the previously deposited sediments.

The thinly bedded carbonate alternates with more massive carbonate and clays in vertical sequences. The massive carbonates are decimetre-thick beds made of poorly indurated dolostone. The dolostone consists of homogeneous, rather porous mosaics of subhedral to rhombohedral, 20-45- $\mu$,m-sized crystals. These carbonates do not show definite features of subaerial exposure and are located in the lower part of the sequences. Thus, the transition from massive dolostones to clay and thinly bedded carbonates upward in the sequence suggests a progressive shoaling of the lake.

\subsection{Open-lake carbonate facies}

This group of carbonates extends into the central area of the basin forming rather monotonous, well-bedded sequences intercalated with thin beds of mudstone (sections VII-IX of Fig. 3). Bed thickness ranges from 10 to $100 \mathrm{~cm}$. The beds are internally massive and consist mostly of dolomite, although calcite is present at the top of the sections. The uppermost deposits were affected by karstification at the beginning of the Late Miocene. Karst-related features are represented by irregular-shaped, large voids ranging a few centimetres to several decimetres in diameter with drusy calcite veneers. Karsting resulted in the calcitization of the uppermost beds of the lacustrine sections.

The open-lake carbonates are weakly indurated and consist of porous aggregates of $\mu$,m-size dolomite crys- 


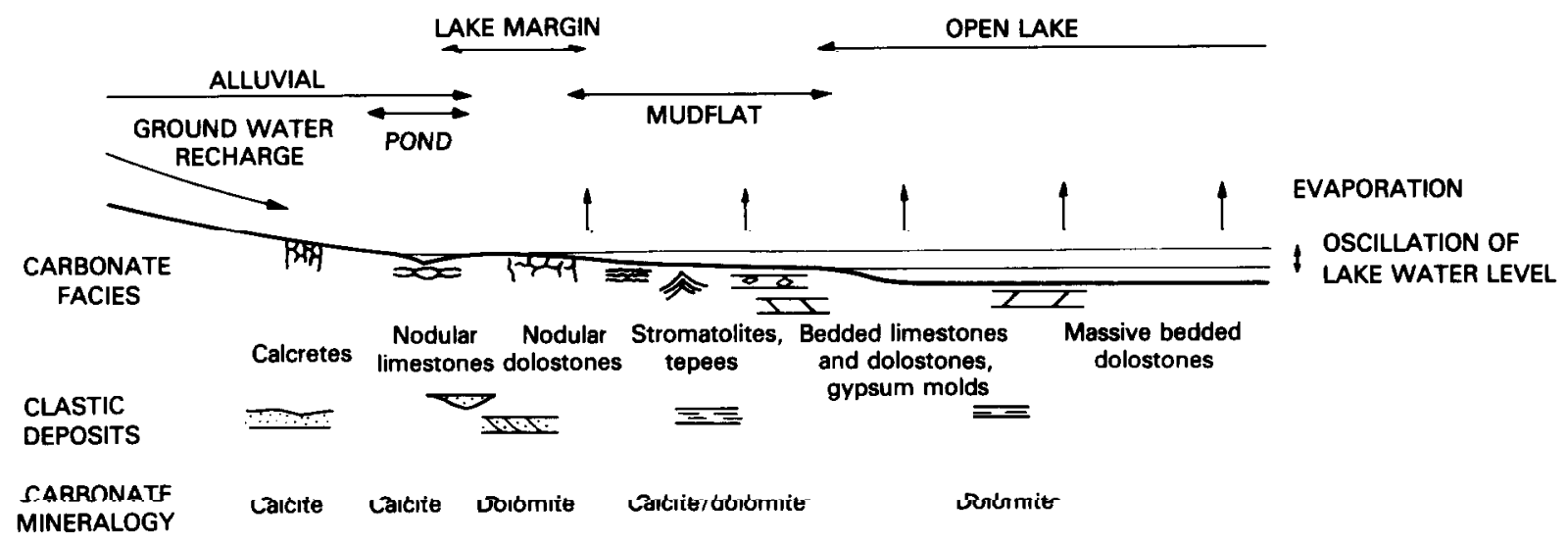

Fig. 4. Idealized sketch of carbonate sedimentary environments in the western side of the Madrid Basin with indication of main carbonate and cla tic facies as well as carbonate mineralogy. Graphic not to scale.

tals. Dispersed fragments of ostracods, gastropods and algal filaments are present but rare.

The paleogeographical distribution of the carbonate facies is sketched in Fig. 4. The shallow nature of the lake is inferred from the sedimentological characteristics of the deposits, particularly from the architecture of the elastic strata (Calvo et al., 1989), as well as from the lateral arrangement of the facies belts. The sedimentary model corresponds to a shallow lake in which water level fluctuated periodically (Calvo et al., 1984). Oxic conditions prevailed throughout the water column in the most open-lake areas.

Lake carbonates are nearly devoid of fossils, suggesting that hydrochemistry of the lake restricted the development of floral and fauna! communities. Only plants, represented by rhizoliths and rare carbonaceous debris, have been recognized in the carbonates. Some poorly preserved remains of gastropods and ostracods have been observed in the open-lake facies. The scarcity of fossils along with the mineralogical and petrographical characteristics of the carbonates suggest that the latter were probably precipitated inorganically. By contrast, organic fabrics are clearly recognized in calcretes, which suggests that plants contributed significantly to carbonate accumulation in this type of facies. No conclusive evidence has been found to support a primary precipitate or secondary replacement origin for the dolomite facies, although the latter mechanism is thought to be more plausible in view of the isotopic results discussed below.

General climatic conditions during the period oflake sedimentation are inferred from paleoecological data furnished by mammal faunas (Lopez Martinez et al., 1987). These faunas are indicative of warm, semi-arid, seasonally-contrasted climatic regimes, probably similar to those found in present-day tropical savanna environments.

\section{Geochemistry}

\subsection{Trace elements}

$\mathrm{Na}, \mathrm{Mn}, \mathrm{Fe}$ and $\mathrm{Sr}$ were selected for analysis because of their significance in carbonate sedimentation and diagenesis. Particularly, Sr content may be a helpful tool for understanding the origin and diagenesis of carbonates (Kinsman, 1969; Veizer et al., 1971; Veizer and Demovic, 1974; Al-Hashimi, 1976; Veizer, 1983). $\mathrm{Li}$ and $\mathrm{K}$ contents were analyzed because of their common occurrence in clays in the Madrid Basin. Other elements, such as $\mathrm{Zn}, \mathrm{Ba}$ and $\mathrm{Pb}$, were also measured, but the contents of these elements did not show significant differences between the various carbonate groups.

Data obtained by trace-element analysis are listed in Table I. The mean values and standard deviations calculated for all elements are presented with respect to the main carbonate facies (Fig. 5). Calcretes, dolocretes, pond deposits, lake margin dolostones and openlake carbonates show a similar range of $\mathrm{Sr}$ content. Mudflat carbonate facies are characterized by higher mean Sr content (Table 3), although Sr contents in this facies are more variable than in the other carbonate types (Fig. 5). This is mainly due to anomalous sam- 

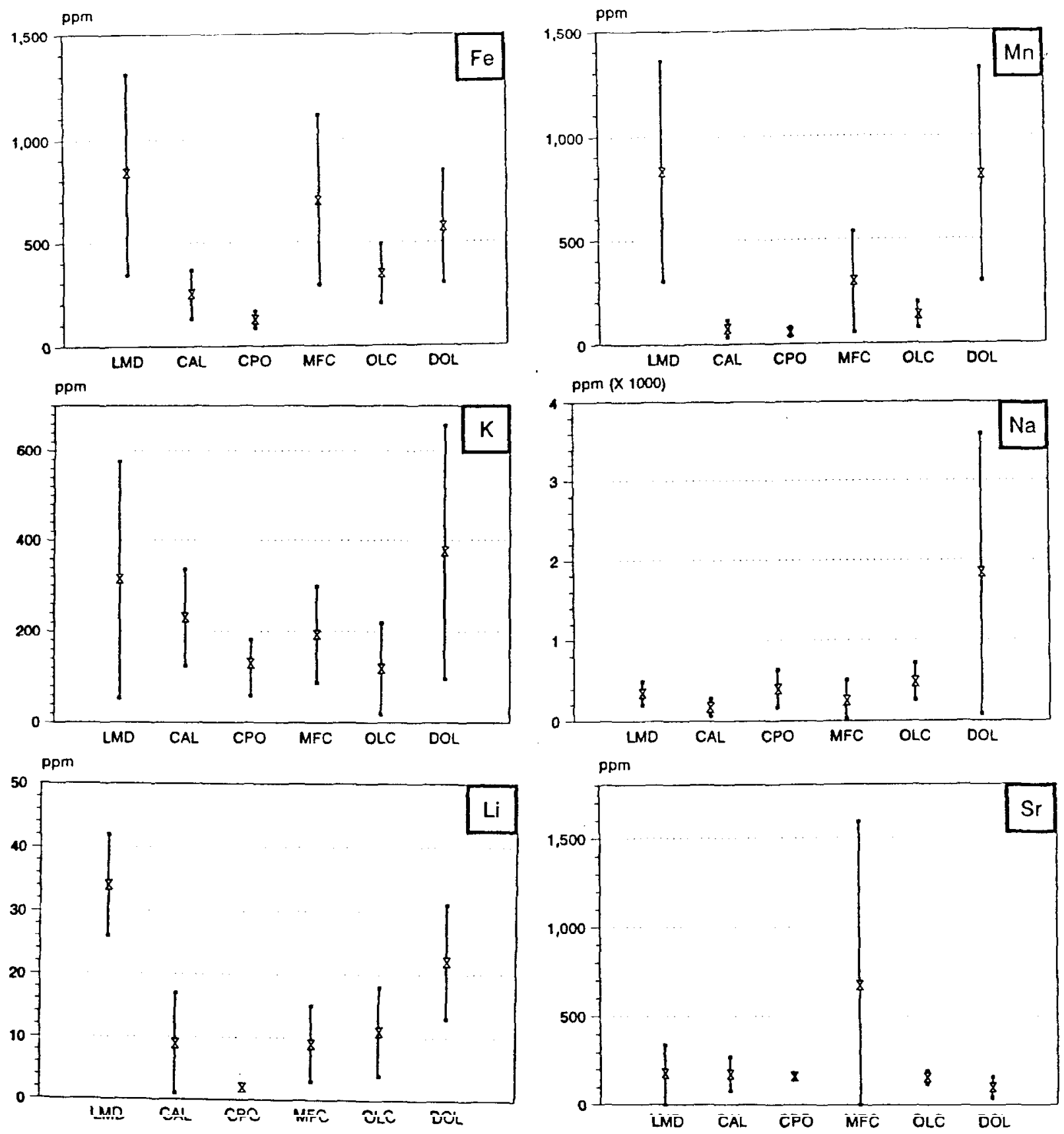

Fig. 5. Graphic representation of mean values (double triangle) and one standard deviation (bars) for the analyzed elements related to the

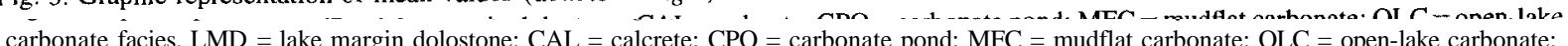
DOL $=$ dolocrete.

pies ( $35,37,38$ ) which consist of calcite microspar mosaics with abundant gypsum molds. Excluding these samples, the mean value of Sr content in the mudflat carbonates is $-370 \mathrm{ppm}$, still higher than in the other facies. In general, the dolomite samples contain less $\mathrm{Sr}$ than the calcite samples. This behaviour agrees with 
Table 3

Mean and standard deviation values (ppm) for trace-element content in the different carbonate facies

\begin{tabular}{|c|c|c|c|c|c|c|c|c|c|c|c|c|}
\hline \multirow[t]{2}{*}{ Carbonate facies } & \multicolumn{2}{|l|}{$\mathrm{Fe}$} & \multicolumn{2}{|l|}{$\mathrm{K}$} & \multicolumn{2}{|l|}{$\mathrm{Li}$} & \multicolumn{2}{|l|}{$\mathrm{Mn}$} & \multicolumn{2}{|l|}{$\mathrm{Na}$} & \multicolumn{2}{|l|}{$\mathrm{Sr}$} \\
\hline & mean & S.D. & mean & S.D. & mean & S.D. & mean & S.D. & mean & S.D. & mean & S.D. \\
\hline Lake margin dolostones & 841 & 499 & 314 & 261 & 34 & 8 & 832 & 529 & 343 & 147 & 179 & 262 \\
\hline Calcretes & 251 & 117 & 230 & 106 & 9 & 8 & 75 & 41 & 169 & 104 & 175 & 97 \\
\hline Carbonateponds & 128 & 40 & 129 & 71 & 2 & 0 & 57 & 22 & 400 & 232 & 163 & 19 \\
\hline Mudflat carbonates & 703 & 411 & 193 & 105 & 9 & 6 & 297 & 241 & 249 & 259 & 673 & 916 \\
\hline Open-lake carbonates & 346 & 143 & 118 & 100 & II & 7 & 136 & 60 & 482 & 229 & 158 & 37 \\
\hline Dolocretes & 573 & 272 & 376 & 280 & 22 & 9 & 810 & 511 & 1,839 & 1,756 & 101 & 60 \\
\hline
\end{tabular}

S.D. = standard deviation

the findings of others that Sr substitutes for Ca rather than $\mathrm{Mg}$ in the dolomite lattice (Behrens and Land, 1972; Kretz, 1982) and that the distribution coefficients for $\mathrm{Sr}$ in dolomite $\mathrm{CK} ; ;$ ) ) are much lower than unity ( Katz and Matthews, 1977; Jacobson and Usdowski, 1976).

$\mathrm{Mn}$ and Fe contents show similar trends in the different facies. The calcites have relatively low $\mathrm{Fe}$ and Mn contents and the dolomites higher values, except for dolostones deposited in open-lake environments. The similar trend shown by $\mathrm{Fe}$ and $\mathrm{Mn}$ may be explained by the geochemical affinity of this pair of elements.

$\mathrm{Li}$ and $\mathrm{K}$ have similar distributions in the different carbonate facies, with a maximum for the lake margin dolostones. The lack of reliable data for distribution coefficients of this pair of elements ( Veizer, 1983) makes it difficult to be conclusive about their mutual

Table 4

Factor analysis. Eigenvalues, total variance and weightings for the variables for each factor

\begin{tabular}{|c|c|c|c|c|}
\hline & & II & III & IV \\
\hline Eigenvalues & 2.55 & 1.26 & 1.08 & 0.83 \\
\hline Total variance (\%) & 36.4 & 18.1 & 15.6 & 118 \\
\hline Total variance (cumulative \%) & 36.4 & 54.5 & 70.1 & 81.9 \\
\hline $\mathrm{Fe}$ & 0.807 & 0.065 & 0.051 & 0.209 \\
\hline$\stackrel{k}{\mathrm{Li}}$ & $\begin{array}{l}\mathbf{n}_{0.19} \\
0.719\end{array}$ & $\begin{array}{l}\text { nM5 } \\
0.294\end{array}$ & $\begin{array}{l}\text { กnh } \\
0.279\end{array}$ & -0.053 \\
\hline Mn & 0.856 & 0.028 & -0.038 & -0.237 \\
\hline $\mathrm{Na}$ & 0.098 & 0.126 & 0.958 & -0.098 \\
\hline $\mathrm{Sr}$ & -0.033 & -0.023 & -0.088 & 0.967 \\
\hline l.R. & 0.072 & 0.919 & -0.044 & -0.121 \\
\hline
\end{tabular}

I.R. = insoluble residues. geochemical behaviour. Finally, Na contents of the limestones are quite similar to values obtained for dolomites in all facies. Only Na content in dolocretes shows higher values, up to $4555 \mathrm{ppm}$, which is probably due to the presence of analcime in some of the samples, especially samples 29, 30 and 58 (Table 1). Excluding these samples, the mean value of $\mathrm{Na}$ in dolocretes is $169 \pm 104 \mathrm{ppm}$, lower than the mean values obtained for the other facies types.

Trace-element contents determined in the carbonate samples were subjected to factor analysis. The analysis reveals the existence of four factors which explain $82 \%$ of the total variance of our data (Table 4). The first factor, which accounts for $36 \%$ of the total variance is related to $\mathrm{Mn}, \mathrm{Fe}$ and $\mathrm{Li}$. The second factor, representing $18 \%$ of the total variance, is related to insoluble residue and potassium. The third and fourth factor components, accounting for $16 \%$ and $12 \%$ of the total variance, are related to $\mathrm{Na}$ and $\mathrm{Sr}$, respectively. Because insoluble residue and $\mathrm{K}$ content are considered to be closely associated with the clay fraction of the samples, we selected the other three factor components for plotting trace-element data from carbonates in a triangular diagram (Fig. 6). In this representation, tields trom the different carbonate facies are only partially discriminated. A discriminant function analysis was carried out

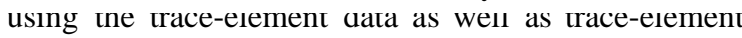

and stable isotope contents combined. As aforementioned, this latter attempt did not lead to signiticant results, which is probably due to the reduced number of isotopic data. By analyzing trace-element content alone, two discriminant functions are defined that represent percentages of $60 \%$ and $21.6 \%$, and canonical correlations of 0.87 and 0.73 , respectively. Standard- 
ized discriminant function coefficients for both functions are given in Table 5. The variable "facies" was used as the classification factor in the analysis. The two main discriminant functions obtained allow plotting of the samples according to their trace-element contents ( Fig. 7) . By this method, fields corresponding to the different facies are well discriminated except for mudflat and open-Jake carbonates. However, the discrimination of carbonate types obtained graphically is only partially in agreement with the classification rates determined from the discriminant function analysis. As deduced from the results shown in Table 6, lake margin dolostones and carbonate ponds are best classified whereas calcretes show the lower classification rates.

\subsection{Isotope geochemistry}

Isotopic analysis were carried out on 32 carbonate samples in order to aid in environmental interpretations as well as to establish geochemical similarities or differences among the carbonate facies. Oxygen and carbon isotopic ratios, expressed as $8^{18} 0$ and $8^{13} \mathrm{C}$, are listed in Table 2.

Only two samples ( 46, 54) contained sufficient amounts of both calcite and dolomite for both to be analyzed; all other analyses were for only one mineral. Dolomite in sample 46 is significantly enriched in ${ }^{13} \mathrm{C}$
Table 5

Standardized discriminant function coefficients

Discriminant function

\begin{tabular}{lrr} 
Fe & -0.487 & -0.206 \\
$\mathrm{~K}$ & 0.407 & -0.112 \\
$\mathrm{Li}$ & 0.874 & 0.663 \\
$\mathrm{Mn}$ & 0.757 & -0.497 \\
$\mathrm{Na}$ & 0.141 & -0.945 \\
$\mathrm{Sr}$ & -0.049 & -0.421 \\
$\mathrm{I} . \mathrm{R}$. & -0.397 & 0.494 \\
\hline
\end{tabular}

Discriminant functions: I (60\% percentile), 2 (21.6\% percentile). I.R. $=$ insoluble residues

and depleted in ${ }^{18} 0$ relative to calcite. In sample 54 , the dolomite is significantly enriched ( by $5-6 \% 0$ ) in both ${ }^{13} \mathrm{C}$ and ${ }^{18} 0$ relative to the calcite. In both cases the relative values of $8^{18} 0$ and $8^{13} \mathrm{C}$ in dolomite and calcite are outside of the usual ranges for coexisting authigenic dolomite and calcite in some recent environments ( Northrop and Clayton, 1966; Khoury et al., 1982).

The isotopic values obtained for different carbonate deposits have been represented in a cross-plotted $8^{18} 0$ 813C diagram (Fig. 8) . In this representation the carbonates are distributed in two broad groups, probably

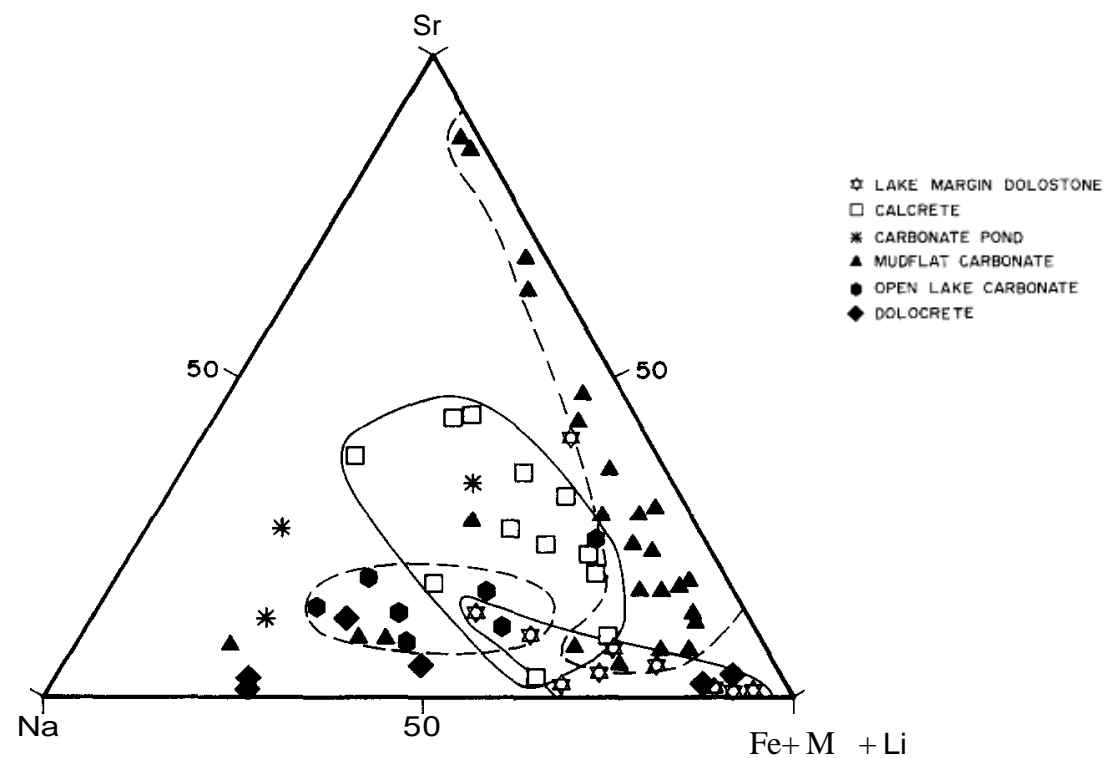

Fig. 6. Sr-Na- $(\mathrm{Fe}+\mathrm{Mn}+\mathrm{Li})$ ternary plot of all study samples. The enclosing circles define fields where the several carbonate types are more densely plotted on the diagram. 


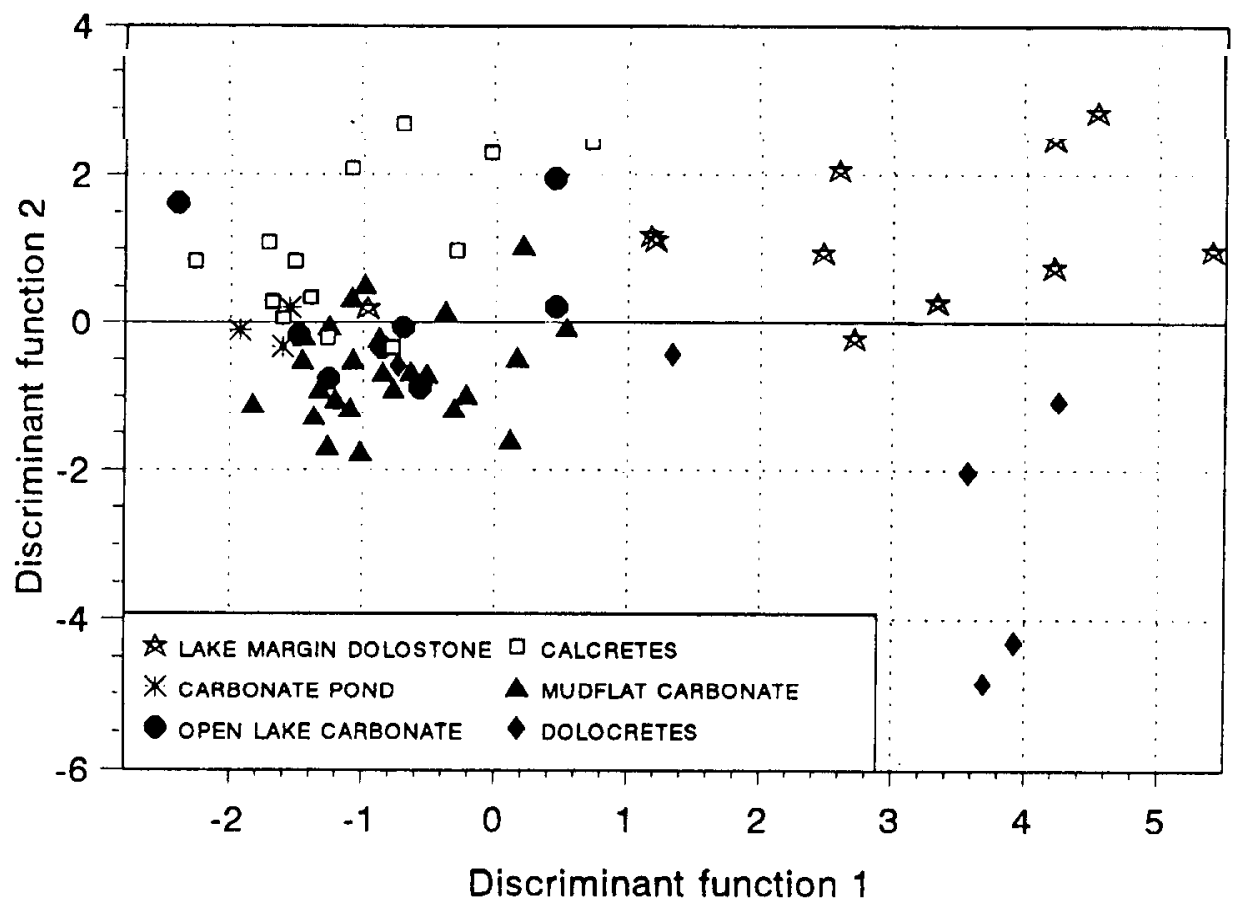

Fig. 7. Discrimination of carbonate facies types.

reflecting different paleoenvironmental conditions of carbonate formation. Calcretes show the most negative values. Carbonate accumulated in ponds is isotopically depleted, similar to calcretes. This confirms the close relationship of paleohydrologic conditions where both types of carbonates were deposited. In contrast, dolocretes show considerably less negative values of both $8^{18} 0$ and $8^{13} \mathrm{C}$. Differences between $8^{18} 0$-values of dolocrete and calcrete suggest that these two types of pedogenic carbonate formed in sedimentary subenvi-

Table 6

Classification rates obtained from discriminant function analysis (\%)

Function analysis (\%)

LMD CAL CPO MFC OLC DOL

\begin{tabular}{lrrrrrr}
\hline $\begin{array}{l}\text { Lake margin dolostone } \\
\quad \text { (LMD) }\end{array}$ & 100 & 0 & 0 & 0 & 0 & 0 \\
Calcretes (CAL) & 0 & 57 & 21 & 7 & 14 & 0 \\
Carbonate pond (CPO) & 0 & 0 & JOO & 0 & 0 & 0 \\
Mudflat carbonate (MFC) & 0 & 0 & 7 & 77 & 15 & 0 \\
Open-lake carbonate (OLC) & 0 & 12 & 0 & 12 & 76 & 0 \\
Dolocretes ( DOL) & 0 & 0 & 0 & 0 & 33 & 67 \\
\hline
\end{tabular}

ronments characterized by distinct hydrochemistry. Thus, isotopic contents of dolocretes show a similarity with those of lake margin dolostones and mudflat carbonate (Fig. 8) which would reflect the influence of the saline lake on the formation of dolocretes.

Carbonate minerals of mudflat facies show more varied isotopic values and, in general, are enriched relative to calcretes and are perhaps slightly enriched in ${ }^{13} \mathrm{C}$ relative to margin dolostones. The variability of isotope compositions within the mudflat carbonate deposits would reflect different subenvironments of carbonate deposition (differences of subaerial exposure ratios, periods of low or high stand in the lake, etc.; Eugster and Kelts, 1983). The dolomite samples, at least samples 46 and 54, seem to be slightly enriched relative to the calcites, but given the small number of samples, the data are not sufficient to conclude a definite trend.

The single open-lake carbonate analyzed (51) is not truly representative of this facies type. Sample 51 was collected from carbonate beds that were strongly affected by karstification at the top of the lacustrine sequences. The interaction of karst-related meteoric water with the lacustrine carbonates could explain the 


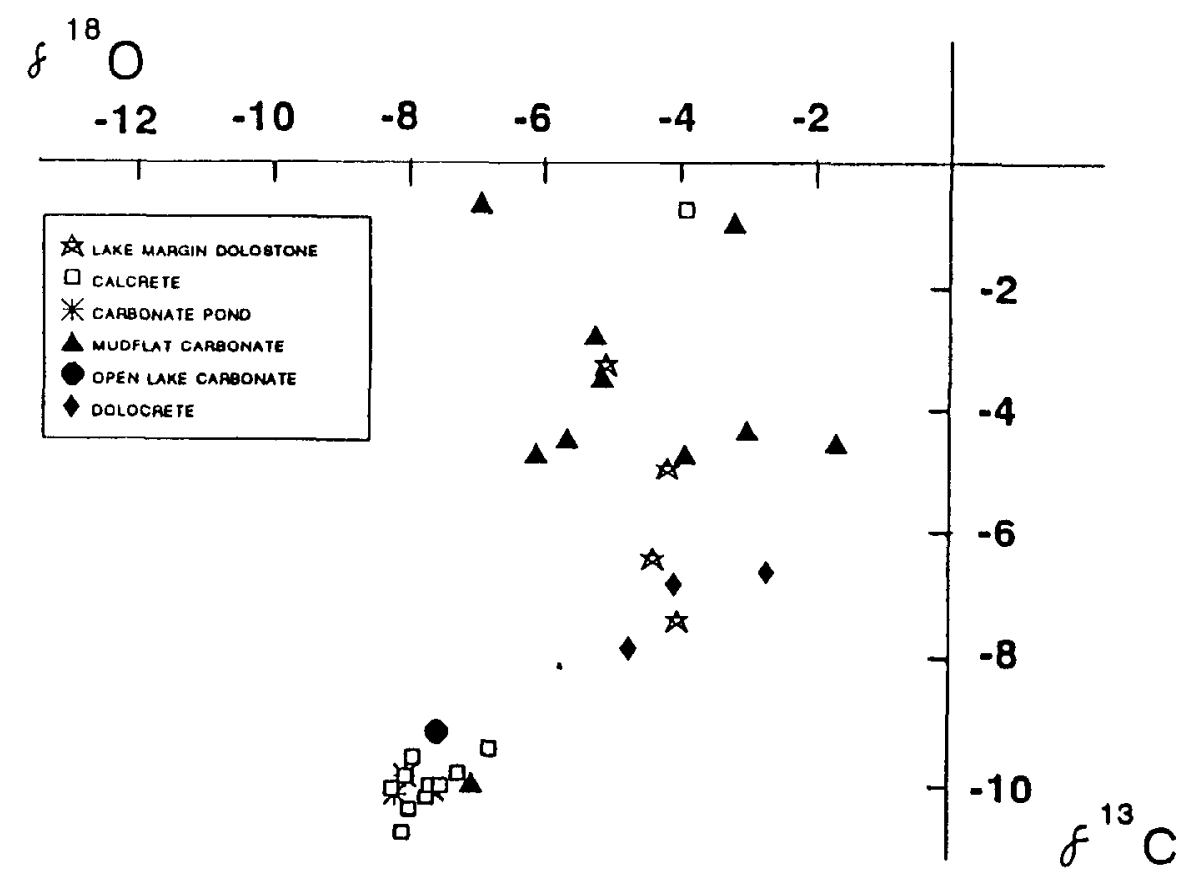

Fig. 8. II"C- $0^{18} 0$ cross-plot of some of the investigated samples. A set of samples comprising calcrete and carbonate pond facies are well differentiated from those samples corresponding to carbonates formed under the influence of the saline lake. The sample from open-lake carbonate is anomalous (seeexplanation in text).

very negative isotopic values measured in this type of carbonate.

\section{Discussion}

One of the aims of this paper is to search the correlation between facies types and trace-element and isotope contents of carbonates deposited in lacustrine and related alluvial facies of the western side of the Madrid Basin. Our results show that, in this context, both sets of data may be considered potential discriminators of paleoenvironments of carbonate deposition. This approach to the use of geochemical data as a tool for interpreting paleoenvironmental conditions of lacustrine carbonate deposition follows those performed by Spencer ( 1982), Molenaar and De Feyter ( 1985), Janaway and Parnell ( 1989), and Cojan et al. (1992), amongst others.

The lacustrine and alluvial related carbonates show a distribution pattern consistent with the preliminary sedimentary model proposed by Calvo et al. ( 1984, 1989). This sedimentary model, sketched in Fig. 4, reflects the geographical distribution of the different alluvial and lake subenvironments, each characterized by distinct hydrological conditions. Because of the lack of carbonate source areas northwest of the basin and the lack of petrographic evidence for detrital carbonate grains, it is assumed that the carbonates are mostly authigenic. Their mineralogical and geochemical characteristics were closely controlled by the parent solution. Organic influence and early or later meteoric diagenetic processes have also affected the primary deposit. Most of the carbonate facies analyzed display textural features indicative of diagenetic transformation. In spite of these changes, the carbonates retain some of the original geochemical imprints so that they may be used to discriminate among different conditions of carbonate formation (e.g., Molenaar and De Feyter, 1985; Platt, 1992).

The morphological features, such as prismatic structure, rhizocretions and clay cutans, displayed by both calcretes of the medial and distal zones of the alluvium and dolocretes are indicative of a pedogenic origin. In all cases, precipitation of carbonate within the soil horizon is thought to have been mainly controlled by the 
combined effect of evaporation and biological activity. In fact, micromorphological features related to roots (alveolar fabrics) are widely recognized within both calcretes and dolocretes. The common pedogenic features recognized in these dolocretes make them different from those formed in phreatic conditions. This latter origin has been suggested as the most frequent mechanism of dolocrete formation (Wright and Tucker, 1991; Spolt and Wright, 1992).

$8^{18} 0$-values determined in most of the calcretes, whether developed on previous soils of medial zones or on distal alluvial fan clays, are clearly negative and would indicate a strong meteoric influence, quite compatible with the pedogenic origin suggested for these deposits (Alonso et al., 1986). The low Sr contents measured in the calcretes corroborate this assumption. Similarly, the negative $\mathrm{O}^{13} \mathrm{C}$-values may be related to biogenic production of $\mathrm{CO}_{2}$ in the soil zone (Cerling and Hay, 1986). Dolocretes have less negative $8^{18} 0-$ and $\mathrm{O}^{13} \mathrm{C}$-values than calcretes. This could be explained by two factors: ( I ) the commonly observed $8^{18} 0$ enrichment in dolomite compared to calcite due to equilibrium isotopic fractionation ( Northrop and Clayton, 1966; Molenaar and De Feyter, 1985); and (2) higher evaporation rates in the area where the dolocretes developed ( Wright and Alonso Zarza, 1992). In both cases, it is assumed that the formation of dolomite in this facies took place under the influence of more saline waters of the adjacent lake.

The presence of analcime in some dolocrete samples requires comment. The occurrence of zeolites formed authigenically in calcareous paleosols has been described from Quaternary arid and semi-arid environments ( Hay, 1978; Watts, 1980; Renaut, 1993) similar to those of the Madrid Basin during the Aragonian. In these settings, zeolites, in particular analcime forms at and close to the land surface mainly through evapotranspiration of shallow lake margin groundwaters. Analcime was probably formed by reaction of alkaline, sodic pore waters with poorly crystalline clays, though other silicates like plagioclase could also contribute (Renaut, 1993).

The similarity between carbonate deposited in ponds and calcretes is better illustrated by isotopic values than by trace-element content. $8^{18} 0$-values for pond carbonates also indicate derivation from meteoric waters. $\mathrm{O}^{13} \mathrm{C}$-values are quite similar and are in agreement with the textural evidence suggesting a contribution of plants to these deposits. Although the sepiolite interbedded with pond carbonate has not been analyzed for isotopic composition, the clearly negative isotopic values for the carbonate seem to corroborate previous statements ( Khoury et al., 1982; Hay et al., 1986; Jones, 1986) on the precipitation of sepiolite without the requirement of extensive evaporative concentration.

The close isotopic relationship between dolocretes and lake margin dolostones ( Fig. 8) supports the hypothesis that the formation of dolomite in the former facies took place under the influence of the adjacent saline lake. A similar situation has been pointed out by Hay et al. (1986) in carbonate deposits of the Amargosa Desert in the western U.S.A. Dolocretes and lake margin dolostones also show striking similarities with regard to trace-element compositions (see Figs. 5 and 6). The common dolomitic nature of both facies accounts for their low Sr contents and concomitant high Fe and Mn contents.

Dolostones constitute the most common carbonate facies in lake margin and open-lake environments, whereas limestones are widely found in the mudflat belt. Dolomite is present in both recent and ancient Jake environments (Muller et al., 1972; Jones and Bowser, 1978; Eugster and Kelts, 1983; DeDeckker and Last, 1989; Last, 1990). Dolostones in our study area fit in the category of penecontemporaneous dolomite sediments which were formed under saline conditions involving concentration of Mg-rich waters. We have no conclusive data to postulate a primary or early diagenetic origin of the dolomite. Some geochemical data suggest the latter mechanism is more probable, as discussed below.

The sedimentological analysis of the lake margin dolostones provides evidence that the dolomite deposits were formed during stages of less water inflow to the lake, accompanied by minor elastic input. Under these conditions, the lake water became progressively concentrated by evaporation, producing enrichment in ${ }^{18} 0$ (Fig. 8). The formation of dolomite could be favored by the presence of $\mathrm{Li}$ (Gaines, 1980) which is abundant in the clays that underlie dolomite beds in the lake margin sequences ( Ribes et al., 1985). Na and Sr contents are low in this type of dolostone ( Fig. 5). The low contents could be related to the early diagenetic origin of these dolostones, linked to the low distribution coefficient values of $\mathrm{Na}$ and $\mathrm{Sr}$ for the dolomite. The 
high $\mathrm{Mn}$ and $\mathrm{Fe}$ contents in these facies can be explained by the combined effect of fixation by plants and lack of further leaching in the dolomite beds. The role of plants is also indicated by the relatively negative $\mathrm{O}^{13} \mathrm{C}$-values obtained for the lake margin dolostone. In addition, some samples from this facies (Fig. 8) show $\mathrm{O}^{13} \mathrm{C}$-values similar to dolocretes in which plant contribution is clearly recognized.

Mudflat carbonate facies are very different from either the calcite found in carbonates that occur in alluvial settings and the dolomite found in central Jake environments. The carbonate deposits included in this

group show the highest variability in terms of both isotopic val ues and trace-element contents. This can be related to the variety of carbonate subtypes that form this major facies group. Petrographic analysis of the mudflat carbonates reveals that many of the calcite mosaics recognized in limestones actually consist of previous dolomite textures that are now calcitized. In some cases, calcitization took place almost simultaneously with the deposition of the primary carbonate, as is indicated by the alternation of thin dolomite and calcite laminae. However, this alternation is not a general feature and calcite is the predominant mineral of many carbonate beds. Calcite is especially prevalent in the carbonate beds that form the upper levels of the lacustrine cycles, which suggests that calcitization could be related to rather short-term periods of exposure.

Finally, the isotopic contents of open-Jake carbonate facies have not been studied in detail. One sample from th is facies falls in the field of calcrete and carbonate pond facies ( Fig. 8) which is explained by the fact that the analyzed material corresponds to open-Jake carbonate that underwent karstification, that is, modification by meteoric fresh water. On the other hand, discrimination of open-lake carbonate from other facies on the basis of trace-element contents is not unequivocal and depends on the method of statistical analysis. Thus, open-lake facies is fairly well discriminated from m udflat carbonate in a triangular Sr-Na- $(\mathrm{Fe}+\mathrm{Mn}+\mathrm{Li})$ representation but the two facies types plot together on a bi-axial diagram derived from discriminant analysis. Accordingly, the use of trace-element contents for recognizing differences seen sedimentologically must be carried out with caution.

\section{Conclusions}

Stable isotope and trace-element analyses appear to be useful for differentiating among the various carbonate types and help in paleoenvironmental interpretation of lacustrine and alluvially-related carbonate facies deposited during the Middle Miocene on the western side of the Madrid Basin. Specifically, $8^{18} 0$-values provide evidence of the different hydrologic conditions, in terms of evaporative concentration and influence of meteoric waters, $i_{18}$ which carbonate deposits were formed. Depleted 0 0-values correspond to calcretes and carbonates that were deposited in ponds at the foot of alluvial fans. The intimate association of sepiolite with these deposits indicates that saline conditions were not req uired for precipitation of this clay mineral. In the same way, $8^{18} 0$-values clearly identify carbonate facies that were deposited in brackish or saline lacustrine environments, although some erratic values, particularly in mudflats may indicate that other factors, such as the interplay with groundwaters could control the geochemistry and mineralogy of this group of carbonates.

$\mathrm{O}^{13} \mathrm{C}$-values are sensitive to the contribution of biogenic $\mathrm{CO}_{2}$, whether in the paleosol profiles or in very shallow lake environments. The commonly observed negative $\mathrm{O}^{13} \mathrm{C}$-values both in calcretes and carbonate ponds agree well with the textural evidence of rootrelated fabrics in these deposits. The relativel y higher $\mathrm{O}^{13} \mathrm{C}$-values in lacustrine carbonates or in paleosols (dolocretes) formed under the influence of the saline lake may be interpreted as resulting from higher organic productivity of the moderately alkaline lake waters.

Trace-element contents do not allow so conclusive results as indicators of the different carbonate facies types, but aid the paleoenvironmental interpretation. In fact, fitness in using trace elements as discriminators of the study carbonates appears to be somewhat dependent on the chosen multivariate statistical method. This is particularly clear for the discrimination between mudflat and open-lake carbonates. Some anomalies, such as those detected for $\mathrm{Na}$ in dolocretes or for $\mathrm{Sr}$ in mudflat carbonates, could be related to early diagenetic products ( zeolites, gypsum ) or indicative of diagenetic, groundwater-related processes affecting the previous carbonates. Sr contents are clearly discriminated according to the carbonate mineralogy ( calcite or dolomite) of the deposits. High Mn contents 
seem to have been more directly related to dolomites but more information is needed to establish the relevance of this element in paleoenvironmental interpretation.

\section{Acknowledgements}

This work was born from a Spanish-American Scientific Cooperation Program ( Project CA-83/007) developed through 1984-1988. The work of the Spanish scientists was also financed by CSIC and CAICYT through the Project PR-84-0078-C02-02. We thank Drs. M.A. Garcfa del Cura and S. Ordonez for their collaboration in some aspects of the work. Drawings were made by J. Arroyo. We are most thankful to R.J. Spencer, W.E. Dean and two anonymous referees for constructive criticism and useful suggestions.

\section{References}

Alberdi, M.T., Hoyos, M. Junco, F., Lopez-Martinez, N. Morales, J .. Sese, C. and Soria, D., 1983. Biostratigraphie et evolution sedimentaire du Neogene continental de l'aire de Madrid. In: Mediterranee -La Neogene continental et !evolution paleoenvironmentale et paleoclimatologique. R.C.M.N.S. (Reg. Comm. Mediterr. Neogene Stratigr.) Interim-Colloq., Montpellier, pp. 15-18.

Al-Hashimi, W.S., 1976. Significance of strontium distribution in some carbonate rocks in the Carboniferous of Northtumberland, England. J. Sediment. Petrol., 47: 771-783.

Allen, P.A. and Collinson, J.D., 1986. Lakes. In: H.G. Reading (Editor), Sedimentary Environments and Facies. Blackwell, Oxford, pp. 63-94.

Alonso, A.M .. Calvo, J.P. and Garcia de! Cura, M.A., 1986. Sedimentologfa y petrologfa de los abanicos aluviales y facies adyacentes en el Ne6geno de Paracuellos de Jarama (Madrid). Estud. Geol. (Madrid), 42: 79-101.

Alonso Zarza, A.M., Wright, V.P., Calvo, J.P. and Garcia de! Cura, A.M., 1992. Soil-landscape relationships in the middle Miocene of the Madrid Basin. Sedimentology, 39: 17-35.

Behrens. E.W. and Land, L.S., 1972. Subtidal Holocene dolomite, Baffin Bay, Texas. J. Sediment. Petrol., 42: 155-161.

Bellanca, A., Calvo, J.P., Censi, P., Neri, R. and Pozo, M., 1992 Recognition of lake-level changes in Miocene lacustrine units, Madrid Basin, Spain -Evidences from facies analysis, isotope geochemistry and clay mineralogy. Sediment. Geol., 76: 135153.

Calvet, F. and Julia, R .. 1983. Pisoids in the caliche profiles of Tarragona, northeast Spain. In: T.M. Peryt (Editor), Coated Grains. Springer, Berlin, pp. 456-473..
Calvo, J.P., Ordonez, S., Hoyos, M. and Garcia de! Cura, M.A., 1984. Caracterizaci6n sedimentol6gica de la Unidad Intermedia del Mioceno de la zona sur de Madrid. Rev. Mat. Proc. Geol., 2: 145-176.

Calvo, J.P., Alonso, A.M. and Garcia de! Cura, M.A., 1986. Depositional sedimentary controls on sepiolite occurrences in Paracuellos de Jarama, Madrid Ba in. Geogaceta, I : 25-28.

Calvo, J.P., Alonso Zarza, A.M. and Garcia del Cura, M.A., 1989. Models of Miocene marginal lacustrine sedimentation in response to varied depositional regimes and source areas in the Madrid Basin (Central Spain). Palaeogeogr., Palaeoclimatol., Palaeoecol., 70: 199-214.

Calvo, J.P., Ordonez, S., Garcia del Cura, M.A., Alonso Zarza, A.M., Bustillo, M. and Fort, R., 1991. Composici6n isot6pica de carbonatos en las sucesiones ne6genas de la Cuenca de Madrid: Valoraci6n de los datos existentes. ICongr. Grupo Esp. Terciario, Vic 1991, Comunicaciones: 59-62.

Caiiaveras, J.C., Calvo, J.P., Hoyos, M. and Ordonez, S.. 1993. Paleomorphologic features of an intra-Vallesian paleokarst, Tertiary Madrid Basin - Significance of paleokarstic surface in continental bain analysis. In: P.F. Friend and J.C. Dabrio (Editors), Spanish Tertiary Ba ins. Cambridge University Press, Cambridge, pp. 270-276.

Cerling, T.E. and Hay, R.L., 1986. An isotopic study of paleosol carbonates from Olduvai Gorge. Quat. Res., 25: 63-78.

Cojan, I., latzoura, A. and Renard, M., 1992. Geochemical approach of paleoenvironments and climate in continental formations ( Upper Cretaceous, Provence, France). In: J.P. Calvo, A.M. Alonso, M.A. Garcia, S. Ordonez, J.P. Rodriguez and E. Sanz (Editors), Geochemical Signals in Lacustrine Sequences. IGCP ( lnt. Geol. Correl. Proj.), Proj. IGCP-324, Annu. Meet.. Madrid, pp. 21-23.

DeDeckker, P. and Last, W.M., 1989. Modern, non-marine dolomite in evaporitic playas of western Victoria, Australia. Sediment. Geol., 64: 223-238.

Doval, M., Calvo, J.P., Brell, J.M. and Jones, B.F., 1986. Clay mineralogy of the Madrid Basin: comparison with other lacustrineclosed ba ins. Abstr. Symp. on Geochemistry of Earth Surface Processes of Mineral Formation, Granada, pp. 188-189.

Esteban, M. and Klappa, C.F., 1983. Subaerial exposure environment. In: P.A. Scholle, D.G. Bebout and C.H. Moore (Editors), Carbonate Depositional Environments. Am. Assoc. Pet. Geol. Mem., 33: 1-96.

Eugster, H.P. and Kelts, K., 1983. Lacustrine chemical sediments. In: A.S. Goudie and K. Pye (Editors), Chemical Sediments and Geomorphology. Academic Press, London, pp. 321-368.

Fritz, P. and Fontes, J.Ch., 1986. Handbook of Environmental Isotope Geochemistry, Vol. 2. Terrestrial Environments, B. Elsevier, Amsterdam, 557 pp.

Gaines, A.M., 1980. Dolomitization kinetics: a recent experimental evidence. In: D.H. Zenger, J.R. Dunham and R.L. Ethington (Editors), Concepts and Models of Dolomitization. Soc. Econ. Paleontol. Mineral., Spee. Pub!., 28: 81-86.

Gasse, F., Fontes, J.Ch., Plaziat, J.C., Carbone!. P., Kaczmarska, I., De Deckker, P., Soulie-Marsche, I., Callo!, Y. and Dupleuble, P.A., 1987. Biological remains, geochemistry and stable isotopes forthereconstruction of environmental and hydrological changes 
in the Holocene lakes from north Sahara. Palaeogeogr., Palaeoclimatol., Palaeoecol., 60: 1-46.

Goldsmith, J.R. and Graf, D.L., 1958. Relation between lattice constants and composition of the Ca-Mg carbonates. Am. Mineral., 43: 84-101.

Hay, R.L., 1978. Geologic occurrence of zeolites. ln: L.B. Sand and F.A. Mumpton (Editors), Natural Zeolites: Occurrence, Properties. Use. Pergamon, Oxford, pp. 135-143.

Hay, R.L., Pexton, R.E., Teague, T.T. and Kyser, T.K., 1986. Springrelated carbonate rocks, $\mathrm{Mg}$ clays, and associated minerals in Pliocene deposits of the Amargosa Desert, Nevada and California. Geol. Soc. Am. Bull., 97: 1488-1503.

Hoyos, M .. Junco, F., Plaza. J.M., Ramirez, A. and Ruiz, J., 1985. El Mioceno de Madrid. In: M.T. Alberdi ( Editor), Geologfa Y paleontologfa de! Terciario continental de la provincia de Madrid. CSIC (Cons. Super. Invest. Cient.), Madrid, pp. 9-16.

Jacobson, R.L. and Usdowski, N.E., 1976. Partitioning of strontium between calcite. dolomite and liquids. Contrib. Mineral. Petrol., 59: 171-185.

Janaway, T.M. and Parnell, J., 1989. Carbonate production within the Orcadian Basin, northern Scotland: a petrographic and geochemical study. Palaeogeogr., Palaeoclimatol., Palaeoecol., 70: 89-105.

Jones. B.F., 1986. Clay mineral diagenesis in lacustrine sediments. U.S. Geol. Surv. Bull.. 1578: 291-300.

Jones, B.F. and Bowser, C.J., 1978. The mineralogy and related chemistry of lake sediments. In: A. Lerman ( Editor), Lakes: Chemistry, Geology, Physics. Springer, New York. N.Y .. pp. 179-235.

Katz, A. and Matthews, A .. 1977. The dolomitization of CaCO,: an experimental study at $252-295^{\circ} \mathrm{C}$. Geochim. Cosmochim. Acta, 41: 297-308.

Kelts. K. and Talbot, M.R., 1990. Lacustrine carbonates as geochemical archives of environ mental change and biotic/abiotic interactions. In: H.M. Tilzer and C. Serruga ( Editors), Large Lakes: Ecological Structure and Function. Springer. Berlin, pp. 288315.

Khoury, H.N., Eberl, D.D. and Jones, B.F., 1982. Origin of magnesium clays from the Amargosa desert, Nevada. Clay, Clay Miner. 30: 327-336.

Kinsman, D.J., 1969. Interpretation of Srn concentrations in carbonate minerals and rocks. J. Sediment. Petrol., 39: 486-508.

Klappa, C.F., 1980. Rhizoliths in terrestrial carbonates: classification, recognition. genesis and significance. Sedimentology, 27: 613-629.

Klovan, J.E. and Billings, G.K., 1967. Classification of geological samples by discriminant-function anal ysis. Bull. Can. Petrol. Geol.. 15: 313-320.

Kretz, R., 1982. A model for the distribution of trace elements between calcite and dolomite. Geochim. Cosmochim. Acta, 46: 1979-1981.

Last. W.M., 1990. Lacustrine dolomite -an overview of modem, Holocene. and Pleistocene occurrences. Earth-Sci. Rev., 27: 221-263.

Lomoschitz. A., Calvo, J.P. and Ordonez, S., 1985. Sedimentologfa de las facies detriticas de la Unidad Intermedia de! Mioceno al Sur y Este de Madrid. Estud. Geol. (Madrid), 41: 343-358.
Lopez Martinez, N., Sese, C. and Herraez, E., 1987. Los yacimientos de micromamiferos de! area de Madrid. Bo!. Geol. Min., 98: 1743.

Martin de Vidales. J.L., Pozo, M., Medina, J.A. and Leguey, S., 1989. Formaci6n de sepiolita-paligorskita en litofacies lutiticocarbonaticas en el sector de Borax-Esquivias (Cuenca de Madrid ). Estud. Geol. (Madrid), 44: 7-18.

Molenaar, N. and De Feyter, A.J., 1985. Carbonates associated with alluvial fans: an example from the Messinian Colombacci Formation of the Pietrarubbia Basin, Northern Marche, Italy. Sediment. Geol., 42: 1-23.

Muller, G., Irion. G. and Forstner, U., 1972. Formation of inorganic $\mathrm{Ca}-\mathrm{Mg}$ carbonates in the lacustrine environment. Naturwissenschaften, 59: 158-164.

Netterberg, F., 1980. Geology of southern Africa calcretes, I. Terminology, description, macrofeatures, and classification. Trans. Geol. Soc. S. Afr., 83: 255-283.

Northrop, D.A. and Clayton, R.N., 1966. Oxygen isotope fractionation in systems containing dolomite. J. Geol., 74: 174-196.

Ordonez, S., Fontes, J.Ch. and Garcia de! Cura, M.A., 1983. Contribuci6 $\mathrm{n}$ al conocimiento de la sedimentogenesis evaporftica en las cuencas de Madrid y de! Duero en base a datos de is6topos estables. ( ouC, $0^{18} 0, y^{14} \mathrm{~S}$ ). $\mathrm{X}$ Congr. Nac. Sedimentol., Menorca, pp. 1.49-1.54.

Ordonez, S., Garcia de! Cura, M.A., Hoyos, M. and Calvo, J.P., 1985. Middle Miocene paleokarst in the Madrid Basin (Spain ) -A complex karstic system. 6th Eur. Reg. Meet., Sedimentol.. IAS ( lnt. Assoc. Sedimentol.), Lleida, Abstr.. pp. 624-627.

Ordonez, S., Calvo, J.P., Garcia de! Cura, M.A., Alonso Zarza, A.M. and Hoyos, M., 1991. Sedimentology of sodi um sulphate deposits and special clays from the Tertiary Madrid Basin (Spain ). In: P. Anadon, L. Cabrera and K. Kelts (Editors), Lacustrine Facies Analysis. Spee. Pub!. Inst. Assoc. Sedimentol., 13: 55-73.

Platt. N.H .. 1992. Fresh-water carbonates from the Lower Freshwater Molasse (Oligocene, western Switzerland ): sedimentology and stable isotopes. Sediment. Geol., 78: 81-100.

Platt, N.H. and Wright, V.P., 1991. Lacustrine carbonates: facies models, facies distributions and hydrocarbon aspects. In: P. Anadon, L. Cabrera and K. Kelts (Editors), Lacustrine Facies Analysis. Spee. Pub!. lnt. Assoc. Sedimentol., 13: 55-73.

Renaut, R.W., 1993. Zeolitic diagenesis of late Quaternary fluviolacustrine sediments and associated calcrete formation in the Lake Bogoria Basin. Kenya Rift Valley. Sedimentology, 40: 271-301.

Ribes, J., Pellicer, M.J. and Ordonez, S., 1985. Contribuci6n al conocimiento geoqufmico de los sedimentos de la Unidad Evaporftica y de la Unidad Intermedia de la Cuenca de Madrid. Abstr. ICongr. Geoquf m., Soria, pp. 93-94.

Sibley, D.F. and Gregg, J.M.. 1987. Classification of dolomite rock textures. J. Sediment. Petrol., 57: 967-975.

Spencer. R.J., 1982. The geochemical evolution of Great Salt Lake. Utah. Ph.D. Thesis. The Johns Hopkins University, Baltimore, Md , 308 pp.

Spoil, C. and Wright, V.P.. 1992. Groundwater dolocretes from the Upper Triassic of the Paris Basin, France: a case study of an arid, continental diagenetic facies. Sedimentology, 39: 1119-1136. 
Talbot, M.R., 1990. A review of the paleohydrological interpretation of carbon and oxygen isotopic ratios in primary lacustrine carbonates. Chem. Geol. ( Isot. Geosci. Sect.), 80: 261-279.

Talbot, M.R. and Kells, K., 1990. Paleolimnological signatures from carbon and oxygen isotopic ratios in carbonates from organic carbon-rich lacustrine sediments. In: B.J. Katz (Editor), Lacustrine Basin Exploration - Case Studies and Modern Analogs. Am. Assoc. Pet. Geol., Mem., 50: 99-112.

Tucker, M.E. and Wright, V.P., 1990. Carbonate Sedimentology. Blackwell, London, 482 pp.

Veizer, J., 1983. Chemical diagenesis of carbonates: theory and application of trace element technique. In: Stable Isotopes in Sedimentary Geology, Ch. 3. SEPM (Soc. Econ. Paleontol. Mineral.) Short Course, I0: 1-IOO.

Veizer, J. and Demovic, R., 1974. Strontium as a tool in facies analysis. J. Sediment. Petrol., 44: 93-115.
Veizer, J., Demovic, R. and Turan, J., 1971. Possible use of strontium in sedimentary carbonate rocks as a paleoenvironmental indicator. Sediment. Geol., 5: 5-22.

Watts, N.L., 1980. Quaternary pedogenic calcretes from the Kalahari (southern Africa): mineralogy, genesis and diagenesis. Sedimentology, 27: 661-186.

Wright, V.P., 1989. Paleosol recognition. In: Paleosols in Siliciclastic Sequences. PRIS ( Postgrad. Res. Inst. Sedimentol.) Short Course Notes, Reading, I : 1-25.

Wright, V.P. and Alonso Zarza, A.M., 1992. Significado de la composici6n isot6pica $\left(8^{18} \mathrm{C}\right.$ y $8^{13} \mathrm{C}$ ) en paleosuelos carbonatados -Mioceno de la Cuenca de Madrid. Geogaceta, 11:61---03.

Wright, V.P. and Tucker, M.E., 1991. Calcretes: an introduction. In: V.P. Wright and M.E. Tucker (Editors), Calcretes. Repr. Ser., Int. Assoc. Sedimentol., 2: 1-22. 